\title{
The Catalyst
}

Volume 3 | Issue 1

Article 3

2013

Mythical Hero versus the Modern Heroine: The Female Hero in Suzanne Collins's The Hunger Games

Dane Moreaux

University of Southern Mississippi, dane.moreaux@eagles.usm.edu

Follow this and additional works at: http://aquila.usm.edu/southernmisscatalyst

Part of the Arts and Humanities Commons

\section{Recommended Citation}

Moreaux, Dane (2013) "Mythical Hero versus the Modern Heroine: The Female Hero in Suzanne Collins's The Hunger Games," The Catalyst: Vol. 3: Iss. 1, Article 3.

DOI: $10.18785 /$ cat.0301.03

Available at: http://aquila.usm.edu/southernmisscatalyst/vol3/iss1/3

This Article is brought to you for free and open access by The Aquila Digital Community. It has been accepted for inclusion in The Catalyst by an authorized administrator of The Aquila Digital Community. For more information, please contact Joshua.Cromwell@usm.edu. 


\section{Mythical Hero versus the Modern Heroine: The Female Hero in Suzanne Collins's The Hunger Games}

Dane Moreaux

$5 / 18 / 2012$ 
Turning the pages of Greek myths, one encounters myriad examples of virile heroes: Perseus's clever slaying of the insurmountable Medusa, Odysseus's fearless fight against the wayward seas, or Hercules's incomparable and infinite strength. The lack of female protagonists in these myths indicates a historical outlook regarding how society thought of heroes: they were almost always men. It is within the contemporary pages of The Hunger Games, however, that author Suzanne Collins refashions this hero of Greek myth. As readers identify the structure of these deadly games within the novel, they may note a parallel with the mythical tale of Theseus and his heroic conquering of the Minotaur in Daedalus's labyrinth. Like Theseus, who "offered himself as one of the [youths and maidens]" who "were, according to custom, drawn by lot to be sent" sacrificially to the Minotaur, Katniss Everdeen volunteers to fight to the death in the Hunger Games (Bulfinch 112). Additionally, Katniss bears striking similarity to the rare Greek heroine, Atalanta. However, while Atalanta and Katniss both thrive in their androgynous dispositions (i.e., as beautiful huntresses), Atalanta's outcome (where she is forced to reconcile her disdain for marriage to a man) does not endure the male writers who crafted her character (e.g., Ovid and Apollodorus) (Hamilton 244). Inspired by Theseus and Atalanta, Suzanne Collins's The Hunger Games cleverly reinterprets heroism through the multi-faceted protagonist, Katniss Everdeen; demonstrating both the possibility of a female hero and the certainty that heroism requires more than mere masculine virility.

When first introduced to Katniss's character, the reader discovers that Katniss embodies the roles of provider — typically considered masculine—and nurturer—-typically considered feminine-for her mother and younger sister, Prim. Following the loss of her father in a coalmining explosion, Katniss acknowledges, "my mother was locked in some dark world of sadness [...] At eleven years old, with Prim just seven, I took over as head of the family. There was no 
choice" (Collins 27). Starting from childhood, Katniss is bogged down by burdens of adult responsibility. With the death of her father, Katniss takes her dad's bow and arrows to the woods, recalls his instruction in the weapon's usage, and risks potential punishment by providing for her family through unlawful hunting. Adding to Collins's interpretive construct of heroism, this fact marks Katniss's paternal and masculine role as hunter, as provider, as father.

With the virtual absence of her negligent mother, Katniss fulfills the maternal and feminine role as nurturer. This becomes evident in the following assertaition when Katniss narrates, "I bought our food at the market and cooked it as best as I could and tried to keep Prim and myself looking presentable" (Collins 27). From the young age of eleven to her youthful, present-day age of sixteen, Katniss overcomes the selfish desire to minimize responsibility for others or whine about the unfortunate lack of a leisurely adolescence. According to Edith Hamilton's Mythology, Theseus similarly "spent his youth [...] in his mother's home [...]" without the presence of a father (209). Nevertheless, Theseus soon leaves his mother for heroic adventure, never leaving his childish enthusiasm nor considering the needs of a mother abandoned by husband and son. Though both Theseus and Katniss convey determination in defeating the odds, Katniss truly begins her role as a heroine through her selfless devotion to family.

Katniss continues to redefine heroism through selflessness when Prim's name is drawn for the reaping (the day in which one boy and one girl are selected to compete to the death in the annual Hunger Games). Katniss instantly volunteers to fight in her sister's stead, which appears to be anomalous when she asserts, "Family devotion only goes so far for most people on reaping day. What I did was the radical thing" (Collins 26). Like Theseus, Katniss exhibits bravery in her willingness to volunteer as a competitor (i.e., "tribute"), but the two heroes differ in their 
intent. While Katniss embraces both aggressive diligence (represented by her persistence to survive) and subdued compassion (signified by her self-sacrifice for others), Theseus merely wants "to become a great hero as quickly as possible, and easy safety was certainly not the way to do that" (Hamilton 210). So whereas, Katniss demonstrates sincerity in her self-sacrifice, while Theseus merely seeks the entitlement of "great hero" (Collins 36). Consider, for example, Hamilton's assertion that "All [...] admired him for his nobility, but they had no idea that he intended to try to kill the Minotaur" (Hamilton 212). I find the citizens' surprise at Theseus's desire to defeat the monster indicates that they presumed he was strictly sacrificing himself in the place of another youth, and the mythical representation of Theseus thereby conveys the hero as more vainglorious than humble.

Conversely, Katniss distances herself from vanity in more ways than one. One way in which Katniss creates this distance is through her evident discomfort with the Capitol's trends. Unlike the other districts that constitute Panem (the dystopian future name for North America), the government's district, the Capitol, displays garb of flamboyant colors and reconstructed fashion norms (e.g., multi-colored hair and men sporting make-up). When Katniss is first trained to act like a lady for her televised interview preceding the games, she becomes frustrated, "I kick off my heels and stomp down to the dining room, hiking my skirt up to my thighs" (Collins 116). Even with her array of fashion choices, Katniss would rather "pull on trousers, a shirt, tuck [her] long dark braid up into a cap, and grab [her] forage bag" to go hunting (Collins 4). That she even tucks up her hair suggests a desire to hide a femininity which is associated with vulnerability. One may describe her choice of attire as masculine (i.e., a pair of pants, shirt, and cap)_ - an indicator of Katniss's separation from gender norms and embrace of her inherent androgyny. 
Katniss shares this androgynous demeanor with the mythical character, Atalanta. Atalanta represents a female protagonist of Greek mythology who is similarly characterized, like Katniss, as androgynous. My interpretation of androgyny is not to be confused necessarily with mere appearance; according to the fifth edition of The American Heritage Dictionary, "androgynous" does not merely entail a biological reference to a hermaphrodite, but is also defined as "[b]eing neither distinguishably masculine nor feminine, as in dress, appearance, or behavior" (“Androgynous"). In The Illustrated Age of Fable, Thomas Bulfinch writes that Atalanta "was a maiden whose face you might truly say was boyish for a girl, yet too girlish for a boy" (104). This description clearly relates a physical notion of androgyny, but it can extend behavior as well. As A.R. Moncrieff's Classic Myth and Legend describes Atalanta:

Thus she grew man-like and hardy, careless of wind or weather, not less bold than beautiful, skilled to handle bow and spear, and more willing to face the fiercest beast than to listen to tender words. All her heart was set on hunting and strenuous exercises, and she thought of men only as comrades in sports, at which few [men] could surpass her by strength or courage. (91-92)

Atalanta does not simply appear boyish; she also acts like one, avoiding feelings of tenderness. Similarily, after volunteering for the games in place of her sister, Katniss's demeanor hardens in the face of cameras, as she remarks, "[I]'ve had a lot of practice at wiping my face clean of emotions and I do this now" (Collins 40). Katniss does not concern herself with being emotive nor ornamenting her appearance. When she arrives at the Capitol, a team of beauticians primp her appearance, shrieking, "You're just so hairy" (Collins 61). Katniss has not found it a necessary to remove her body hair prior to this moment, indicating her indifference to a social construct: women remove body hair in order to remove masculinity. In this way, both female 
characters—Katniss and Atalanta—redefine the aesthetics of beauty, maintaining an amalgamation of both masculinity and femininity.

Though Atalanta and Katniss appear tomboyish and engage in boyish activity, men nevertheless admire their "beauty." Peeta (the boy selected from Katniss's district for the games) and Gale (Katniss's best friend) both vie for Katniss's affection. Gale asks Katniss to go with him and "Leave the district. Run off. Live in the woods" (Collins 9). Peeta even announces his secret love for Katniss to a live broadcasted audience during his interview before the games, but Katniss reverts to her strategic nature as huntress, believing Peeta's proclamation to be a scam. Fueled by aggressive anger at this thought, Katniss shoves Peeta screaming, "He made me look weak" (Collins 135). Katniss remains humble and unaware, incapable of acknowledging herself as beautiful. Haymitch addresses this level of ignorance by asserting, "Do you think he hurt you? That boy just gave you something you could never achieve on your own. [...] He made you look desirable" (Collins 135). Katniss, like Atalanta, does not instantly revert to tenderness or flattery but rather looks to her athletic gifts; recalling her own interview, she admits, "Haymitch is right. I survived my interview, but what was I really? A silly girl spinning in a sparkling dress. Giggling. [...] [I]'m forgettable. [...] No, not entirely forgettable, I have my eleven in training" (Collins 136). Katniss separates herself from female ornament, deeming it silly and frivolous; instead, she focuses on her athletic distinction, recalling her unmatched score of eleven given by the judges for her training abilities. Katniss remains like the hero Atalanta, whose "[H]eart was set on hunting and strenuous exercises, and [...] thought of men only as comrades in sports, at which few [men] could surpass her by strength or courage" (Moncrieff 92). Katniss does not want to be depicted as "a heartbreaker" with "boys back home fall[ing] longingly at [her] feet" nor "star-crossed lovers" with Peeta (Collins 135). Katniss 
merely wishes to be her own individual, unconsciously exhibiting masculine and feminine stereotyped traits in her comportment as much as in her appearance.

I say "unconsciously" because Katniss's gender identity was instinctively formed from the moment she took on the roles of both parents - father and mother-and survivor as hunter and provider. In The Female Hero in Folklore and Legend, Tristram Potter Coffin highlights man's established "role as possessor, protector, and provider, while his mate, almost always vulnerable, found herself being possessed, protected, and provided for" (2). However, Collins constructs a world that inverts this notion of male agency and female passivity. The Hunger Games breaks free of this convention as Katniss protects and provides for her family and the helpless Peeta during the games. During the games, Peeta finds himself brutally injured, leaving Katniss to heal him and keep him safe from the savage competitors. Katniss possesses agency as a hero at this point, risking her own life to save Peeta's; Peeta becomes the vulnerable "female" or damsel in distress, even proudly telling Katniss, "What do I care? I've got you to protect me now" (Collins 312). Haymitch and Peeta's mother even acknowledge this notion of gender inversion: Haymitch describes Peeta as possessing "self-deprecating humor" (an awareness of his self-emasculation), while Katniss “come[s] across more as sullen or hostile," thus masculinized with aloof aggression; Peeta recalls his last words shared with his mother before the games, stating to Katniss, "[S]he says maybe District Twelve will finally have a winner. Then I realized, she didn't mean me, she meant you! [...] She said, 'She's a survivor, that one. She is" (Collins 90, 116). The italicized "She" highlights both literally and figuratively the idea of a female surpassing a man and claiming her rightful status as a potential hero. The roles of gender thus become reversed, and heroism is redefined. 
Katniss's androgynous demeanor should not be confused with sexual orientation. As Judith Butler asserts, "We cannot predict on the basis of what gender a person is" nor what sexual orientation the person shall adopt (Butler 79). Though Katniss comfortably reasserts her gender identity as androgynous, she is not necessarily homosexual. In fact, Katniss exhibits heterosexual behavior when tending to Peeta's injuries in a hollow cave. Initially believing the label of "star-crossed lovers" a ploy meant to gain sponsorship for her and Peeta's survival, Katniss later relates, "[Peeta's] hand brushes the loose strands of my hair off my forehead. Unlike the staged kisses and caresses so far, this gesture seems natural and comforting. I don't want him to stop and he doesn't" (Collins 265). Katniss begins to experience sincere affection for Peeta and equally enjoys the genuine care that Peeta reciprocates. In this light, Katniss and Peeta represent a pair that balances each other's inverted roles of masculinity (Katniss) and femininity (Peeta. To be a hero, one must be willing to accept and acknowledge assistance from another individual.

Theseus, however, focuses solely on his own ambition of becoming a hero, never acknowledging aid from anyone. To define Theseus's ambitions as selfish, one need only reference Ariadne. It is actually by Ariadne's solution to the mystery of the labyrinth that Theseus is able to find his way out; yet, he never truly expresses gratitude nor acknowledges her assistance. In fact, Theseus originally promises to marry Ariadne in exchange for her assistance only to end, according to Hamilton, with "One story say[ing] that Theseus deserted [her]" (215). Theseus lacks the honor (at least in this account) that Katniss possesses as she acknowledges that Peeta saved her life by giving her a loaf of bread and the assistance little Rue gives her during the games. And she empathizes with the death of Thresh—-the boy from Rue's district who spared Katniss's life for her kindness to Rue. Further still, Katniss does not abandon Peeta, 
unlike Theseus who abandons the princess Ariadne for his own blinding, selfish desire to be a hero.

Though other accounts of Theseus's treatment of Ariadne may differ from Hamilton's, that fact is muted by Theseus's heroic slaying of the Minotaur. If the tables were turned, would a woman still be remembered as a hero upon abandoning a man who helped her thrive? Do the constructs of heroism thus differ from men to women? According to The Female Hero in American and British Literature, "the myth of romantic love is held out to women as their version of the heroic quest" (Pearson, Pope 40). In Atalanta's myth, for example, Atalanta intentionally avoids romance, and thus seems to break free of the convention of finding love in order to become a female hero. However, she is outwitted by a young man who competes against her in a race. Atalanta had mockingly "imposed a condition which was generally effectual in relieving her of [a suitor's] persecutions_-'I will be the prize of him who shall conquer me in the race; but death must be the penalty of all who try and fail" " (Bulfinch 104). The young man implores the help of Venus, the goddess of love (or Aphrodite in Greek mythology), who gives him three golden apples that shall entice anyone who looks upon them; he uses these three apples during the race to beat Atalanta, winning her as a wife, and forcing her back into the gender conventions she wished to avoid.

Why then, with such a forward-thinking approach as Atalanta's myth would the writer have Atalanta succumb to male oppression once more? Hamilton states that "Atalanta's story is told in full only by the late writers Ovid and Apollodorus [...]" (244). This perhaps indicates ambivalence from the male writers who crafted Atalanta's character. Author Sarah Pomeroy asserts, "A fully realized female tends to engender anxiety in the insecure male. Unable to cope with a multiplicity of powers united in one female, men from antiquity to the present have 
envisioned women in 'either-or' roles" (8). Atalanta's proficiency as huntress and unmatched agility surpassed the skills of men; consequently, her character was incapable of getting far-a woman must be "either" a wife "or" a mother, "either" submissive "or" feisty—she cannot be multi-faceted, for it shall corrupt the gender hierarchy that men wished to rule, even in the literary world: A man was able to outwit Atalanta by imploring the help of a goddess; Atalanta, in the end, was tempted by an apple.

In The Hunger Games, however, Katniss Everdeen utilizes the apples that appear within her story to her advantage. The first instance occurs during a private session with the judges and creators of the games. Since she is the penultimate tribute to show her talents, the judges are tired, disinterested, and potentially drunk by this point in the day. Frustrated by not being noticed or appreciated, Katniss impulsively shoots an arrow directly into the apple held by a roasted pig's mouth that rests on the table of the judges' private room. Because of this daring action, the judges are forced to confront Katniss's aggression and determination; they give her an outstanding score, eleven out of twelve. Later, apples are a means of survival against the Careers- the top-scoring tributes who band together in the beginning of the games. Katniss shoots a bag of apples that hang above the Careers' stash of food and supplies, which is boobytrapped with mines: "For a moment, everything seems frozen in time. Then the apples spill to the ground, and I'm blown backward into the air" (Collins 221). Unlike Atalanta, Katniss individuates herself from the conventions of gender that attempt to dictate her fate. In the end, Katniss survives both the Hunger Games and the typically male heroism set by Greek myth—and so it seems that the odds appear to be ever in both her and humankind's favor. 
Works Cited

"Androgynous." The American Heritage Dictionary. 5th ed. 2011. Print.

Bulfinch, Thomas. Bulfinch's Mythology: The Illustrated Age of Fable. New York: Stewart, Tabori \& Chang, 1998. Print.

Butler, Judith. "Undiagnosing Gender." Undoing Gender. New York: Routledge, 2004. 75-101. Print.

Coffin, Tristram P. "Of Ladies and Legends." The Female Hero in Folklore and Legend. New York: Seabury, 1975. 1-12. Print.

Collins, Suzanne. The Hunger Games. New York: Scholastic, 2008. Print.

Estés, Clarissa P. "La Selva Subterránea: Initiation in the Underground Forest." Women Who Run with the Wolves: Myths and Stories of the Wild Woman Archetype. New York: Ballantine, 1992. 387-455. Print.

Hamilton, Edith. Mythology. 1942. Boston: Little, Brown and Company; New York: Back Bay Books, 1998. Print.

Moncrieff, A.R. H. Classic Myth and Legend: With Illustrations in Colour and Monochrome from Famous Paintings and Statuary. London: Gresham Pub., 1912. Print.

Pearson, Carol, and Katherine Pope. "The Mirror and the Cage." The Female Hero in American and British Literature. New York: R.R. Bowker, 1981. 16-60. Print.

Pomeroy, Sarah B. Goddesses, Whores, Wives, and Slaves: Women in Classical Antiquity. New York: Schocken, 1975. 1-15. Print.

"Transgenderism". OED Online. March 2012. Oxford University Press. 11 April 2012 <http://www.oed.com.logon.lynx.lib.usm.edu/view/Entry/258307?redirectedFrom=transg enderism $>$. 